Article

\title{
Industrial or Traditional Bamboo Construction? Comparative Life Cycle Assessment (LCA) of Bamboo-Based Buildings
}

\author{
Edwin Zea Escamilla ${ }^{1, *}$, Guillaume Habert ${ }^{2}$ (D), Juan Francisco Correal Daza ${ }^{3}$ (D), \\ Hector F. Archilla ${ }^{4}$, Juan Sebastian Echeverry Fernández ${ }^{3}$ and David Trujillo ${ }^{5}$ \\ 1 Centre for Corporate Responsibility and Sustainability, University of Zürich, 8001 Zürich, Switzerland \\ 2 Institute of Construction Management, ETH Zürich, 8092 Zürich, Switzerland; habert@ibi.baug.ethz.ch \\ 3 Department of Civil and Environmental Engineering, Universidad de los Andes, 111711 Bogotá, Colombia; \\ jcorreal@uniandes.edu.co (J.F.C.D.); js.echeverry103@uniandes.edu.co (J.S.E.F.) \\ 4 Amphibia-BASE \& Visiting Research Fellow, University of Bath, Bath BA2 7AY, UK; hector.archila@bath.edu \\ 5 School of Energy, Construction and Environment, Coventry University, Coventry CV1 5FB, UK; \\ aa7170@coventry.ac.uk \\ * Correspondence: edwin.zea@ccrs.uzh.ch; Tel.: +41-788481531
}

Received: 29 May 2018; Accepted: 28 August 2018; Published: 30 August 2018

\begin{abstract}
The past five decades have witnessed an unprecedented growth in population. This has led to an ever-growing housing demand. It has been proposed that the use of bio-based materials, and specifically bamboo, can help alleviate the housing demand in a sustainable manner. The present paper aims to assess the environmental impact caused by using four different construction materials (bamboo, brick, concrete hollow block, and engineered bamboo) in buildings. A comparative life cycle assessment (LCA) was carried out to measure the environmental impact of the different construction materials in the construction of single and multi-storey buildings. The LCA considered the extraction, production, transport, and use of the construction materials. The IPCC2013 evaluation method from the Intergovernmental Panel on Climate Change IPCC2013 was used for the calculations of $\mathrm{CO}_{2}$ emissions. The assessment was geographically located in Colombia, South America, and estimates the transport distances of the construction materials. The results show that transportation and reinforcing materials significantly contribute to the environmental impact, whereas the engineered bamboo construction system has the lowest environmental impact. The adoption of bamboo-based construction systems has a significant potential to support the regenerative development of regions where they could be used and might lead to long-lasting improvements to economies, environments, and livelihoods.
\end{abstract}

Keywords: bamboo; glue-laminated bamboo; life cycle assessment; $\mathrm{CO}_{2}$

\section{Introduction}

In 2018, the global human population reached 7.6 billion [1], with more than $54 \%$ living in urban areas [2]. The steady growth of these figures hinders the achievement of the goals and targets recently agreed by governments and the United Nation (UN)'s Sustainable Development Goals [3], and in particular, the goals related to the provision of dignified, resilient, and sustainable housing for all [4]. The global housing demand is a multi-faceted problem that requires not only the delivery of housing units, but also requires ensuring their affordability and guaranteeing access to the resources needed to produce them [5]. The UN Habitat estimated in their 'State of the Cities' report that one billion new housing units will be needed worldwide by 2025 [6]. The global housing demand is concentrated in less developed and emerging economies countries from Africa, Asia, and Central and South America. 
Furthermore, current practices within the construction sector results in an ever-increasing consumption of energy and depletion of natural resources [7]. The levels of extraction of construction minerals has also reached new levels in the 21st century, highlighting not only the problem of the resources' availability, but also their accessibility [8]. For instance, the production of construction materials such as cement and aggregates is using $30 \%$ to $40 \%$ of world's energy production [9], and under the current practices, this means that they account for $30 \%$ of global greenhouse gas (GHG) emissions $[10,11]$.

Therefore, it is imperative to explore the potential environmental benefits from the adoption of alternative low-carbon construction materials, including amongst these, bio-based materials such as bamboo and timber. Bio-based construction materials are renewable, and with adequate management, their production can be sustained over long periods of time. Moreover, during their growth phase, they capture atmospheric $\mathrm{CO}_{2}$ and store it in their tissues [12,13]. If these materials are used in durable products, such as buildings and their constituent materials, then the release of the captured $\mathrm{CO}_{2}$ can be delayed as long as the buildings are in service [14]. In the case of bamboo, due to its heterogeneous growth, only $25 \%$ of the culms are harvested annually [12]. As a result, a plantation is always standing, capturing $\mathrm{CO}_{2}$ and producing readily feedstock for its potential use as a construction material [12].

Bamboo has been used as a construction material for centuries all over the world, and traditional bamboo building systems are widespread, particularly in Latin America [15,16]. Earthquake-prone countries such as Colombia, Ecuador, and Peru have adopted bamboo culms as a structural material within their building codes for walling and framing systems for housing of up to two storeys $[17,18]$. The most common structural system is known in Spanish as 'bahareque encementado', and consists of load-bearing bamboo walls that are plastered with cement mortar for weathering protection and structural integrity [19]. However, the three main limitations of this system are (a) its current maximum height limitation to two storeys, (b) that it uses a significant amount of cement, aggregates, and steel for the reinforcement and plaster of the walls, and (c) the use of whole bamboo culms makes construction processes labor-intensive $[19,20]$. These limitations render it unsuitable for multi-storey buildings that can address the need for high-density construction in growing urban centers.

As a way to tackle these issues, new construction methods using engineered bamboo products (EBPs) for structural elements has been proposed. These systems use glue-laminated bamboo elements that are similar to Glulam and other laminated timber products [21-24]. The use of glue-laminated bamboo enables higher levels of industrialization and the standardization of bamboo-based construction materials, thus making their properties more reliable, and their adoption much simpler in terms of design and construction [21,25-29]. This potentiates an increase in the number of storeys that can be built, leading to buildings that are better suited to a dense urban context. Additionally, the use of EBPs in building systems, instead of bamboo culms, can significantly reduce the carbon footprint of new builds. A recent study by Vogtländer et al. [30] estimated that EBPs such as laminated bamboo panels (plybamboo) are capable of sequestering $12.85 \mathrm{~kg} \mathrm{CO}_{2}$ per $\mathrm{kg}$ of product, whilst round bamboo poles (culms) sequester $5.69 \mathrm{~kg} \mathrm{CO} 2$ per $\mathrm{kg}$ of product; both estimations referred to equivalent kilograms of $\mathrm{CO}_{2}$ in the plantation. Furthermore, it should be noted that one hectare of Guadua angustifolia Kunth (a woody bamboo species) can yield enough raw material to produce up to $60 \mathrm{~m}^{3}$ of EBPs in a year [21,31].

Life cycle assessment (LCA) can be used in order to quantify the potential benefits of these remarkable characteristics of bamboo-based construction materials. LCA has been established as the main methodology to quantitatively assess the environmental impacts related to the production and use of goods throughout their service life [32]. Nevertheless, the application of LCA faces several challenges [33] with regards to (a) impact allocations [34,35]; (b) end-of-life scenarios [36,37]; (c) system boundaries [38]; and more importantly, (d) the availability and quality of the reported data [39-41]. The models used in an LCA propose a cause-effect relationship between the environment and human activities to highlight their impacts and consequences [42]. The two main approaches for the use of LCA can be identified as input-output and process-based LCA [43]. The methodologies for carrying out LCA are defined by ISO standard 14040 [44]. Four main steps are implemented. (i) Definition of goal and scope: This step is critical for any LCA, and describes the assessment aim and its geographical, 
physical, and time-related boundaries. (ii) Definition of life cycle inventories (LCI): In this section, all of the input flows, including material and energy, are accounted for each product. (iii) Impact assessment: In this section, the environmental impacts of each of the inputs from the LCI are calculated using specific evaluation methods. (iv) Interpretation of results: In this section, the LCA's results are analyzed and communicated.

LCA has been extensively used to assess the environmental performance of all types of buildings [32]. One of the main features of LCA is that it can be used to identify the most promising strategies for improving the environmental performance of products throughout their service life and supply chain [42]. A building's LCA can be divided into four phases (i) the production and transport of construction materials, (ii) the construction phase, (iii) the use/operational phase, and (iv) the demolition phase [45]. The use of LCA for buildings is challenging due to the intrinsic diversity of the data in these types of assessments. Furthermore, in order to maximize its potential, an LCA should be conducted at the early building-design stages when it is still possible to make substantial changes to the design [42,46]. However, this is the period when the least amount of information is available, and comes at the cost of higher uncertainties regarding the construction materials to be used, their production efficiency, and transportation logistics [47,48].

The present study aims to assess the environmental impact from the use of four construction materials (bamboo, brick, hollow concrete block, and glue-laminated bamboo) in buildings and determine the potential benefits-in terms of $\mathrm{CO}_{2}$ savings-from the use of traditional or bamboo-based construction systems in single and multi-storey buildings. The assessment will use Colombia, South America, as the case study location. Timber has been excluded from the list of materials to be considered, because its use is not currently common or widespread in Colombia; although some commercial reforestation projects do exist, they are not yet making a significant impact in the construction market.

\section{Materials and Methods}

This section describes the methodological steps of the life cycle assessment: (i) definition of goal and scope, (ii) definition of life cycle inventories, and (iii) impact assessment. Step (iv), interpretation of results, will be presented within the 'Results' and 'Discussion' sections of this paper.

The LCA undertaken followed the methodology from ISO 14040 [44] alongside SIMApro v8 software [49], and the EcoInvent v3.0 LCA database [50]. The life cycle impact assessment was calculated using the evaluation method from the Intergovernmental Panel on Climate Change IPCC2013 [51]. In order to achieve the proposed objectives, two comparative LCAs were carried out: one for single-storey housing (SSH) with a living area of about $18 \mathrm{~m}^{2}$, and a second one for a five-storey house with $1100 \mathrm{~m}^{2}$ of living area, which will be referred to as the multi-storey building (MSB). For the $\mathrm{SSH}$, four structural construction materials were considered: brick, bamboo, concrete hollow block (CHB), and glue-laminated bamboo (GLB). For the MSB, two construction approaches were considered: mineral-based (brick, concrete, steel) and bio-based (GLB). In both cases, the structures were calculated to comply with the Colombian Building code NSR-10 [17], and to be able to respond to the required design loads, including earthquake and wind.

\subsection{Definition of LCAs' Goal, Scope, and Functional Units}

The main goal was to quantify the environmental impact related to the use of different construction materials in the production of single and multi-storey buildings. The LCA followed the life cycle phases as described on the European Norm EN 15978 [52], considering two stages-A1-3 Product and A4-5 Construction process - and five phases: (A1) Extraction of raw materials, (A2) Transport, (A3) Manufacturing, (A4) Transport scenario, and (A5) Construction scenario, as presented in Figure 1. 


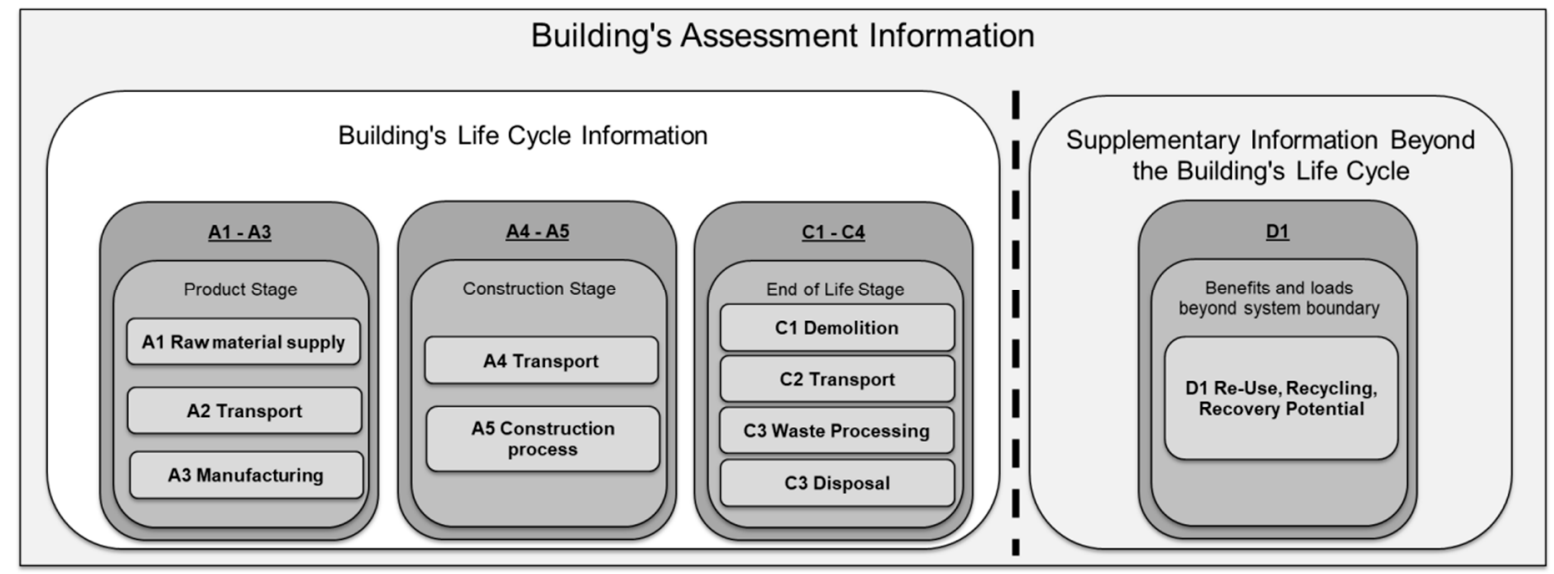

Figure 1. Life cycle phases according to EN 15978.

For the present project, the End-of-life phase (C1-C4) was not considered due to the inherent uncertainty of it. In the case of buildings, the end of life will occur in an unknown future, and it is very difficult to assert what will be the future regulatory and economic conditions. The LCA accounted for the amount of construction materials required for the load-bearing and non-load bearing elements of the buildings. The production of the materials and buildings was geographically located in Colombia, and the estimated transport distances of construction materials was based on the country's cities and regional administrative boundaries [53]. The use, or operational, phase of the buildings was not considered either, due to the specific climatic and technical conditions of Colombia, where artificial heating and cooling is uncommon, and therefore the main energy demand during this phase is for appliances and artificial lighting, neither of which is material-dependent.

The functional unit was defined as the environmental impact related to the production and transport of construction materials per square meter of living area of each building $\left(\mathrm{kgCO}_{2} \mathrm{Eq} / \mathrm{m}^{2}\right)$. This functional unit was chosen to represent the features of each construction technique. As previously highlighted, the plastered bamboo frame (bahareque encementado) technique cannot be used in multi-storey buildings, whilst engineered bamboo could potentially be used in both single and multi-storey buildings. The bill of materials for the single-storey house (SSH) and the multi-storey building (MSB) are presented in Table 1. The main dimensions for the SSH and MSB are presented on Figures 2 and 3 respectively.

Table 1. Bill of materials for SSH and MSB.

\begin{tabular}{|c|c|c|c|c|c|c|}
\hline \multirow{2}{*}{ Materials } & Bamboo SSH & Brick SSH & CHB SSH & GLB SSH & Brick/Concrete MSB & GLB MSB \\
\hline & kg & kg & kg & kg & kg & kg \\
\hline Bamboo pole & 562 & 0 & 0 & 0 & 0 & 0 \\
\hline Brick & 0 & 5307 & 0 & 0 & 474,000 & 0 \\
\hline Concrete & 4332 & 4309 & 4309 & 3975 & 490,022 & 205,760 \\
\hline $\begin{array}{l}\text { Concrete hollow } \\
\text { block (CHB) }\end{array}$ & 120 & 0 & 3816 & 0 & 0 & 0 \\
\hline Flattened bamboo & 216 & 0 & 0 & 0 & 0 & 0 \\
\hline $\begin{array}{l}\text { Glue-laminated } \\
\text { bamboo (GLB) }\end{array}$ & 0 & 0 & 0 & 858 & 0 & 38,341 \\
\hline Plaster cement & 1944 & 1351 & 1351 & 437 & 120,708 & 19,530 \\
\hline Reinforcing steel & 60 & 452 & 565 & 200 & 1682 & 0 \\
\hline Timber & 58 & 0 & 0 & 494 & 0 & 30,180 \\
\hline
\end{tabular}

Source: Authors. SSH: single-storey house; MSB: multi-storey building. 


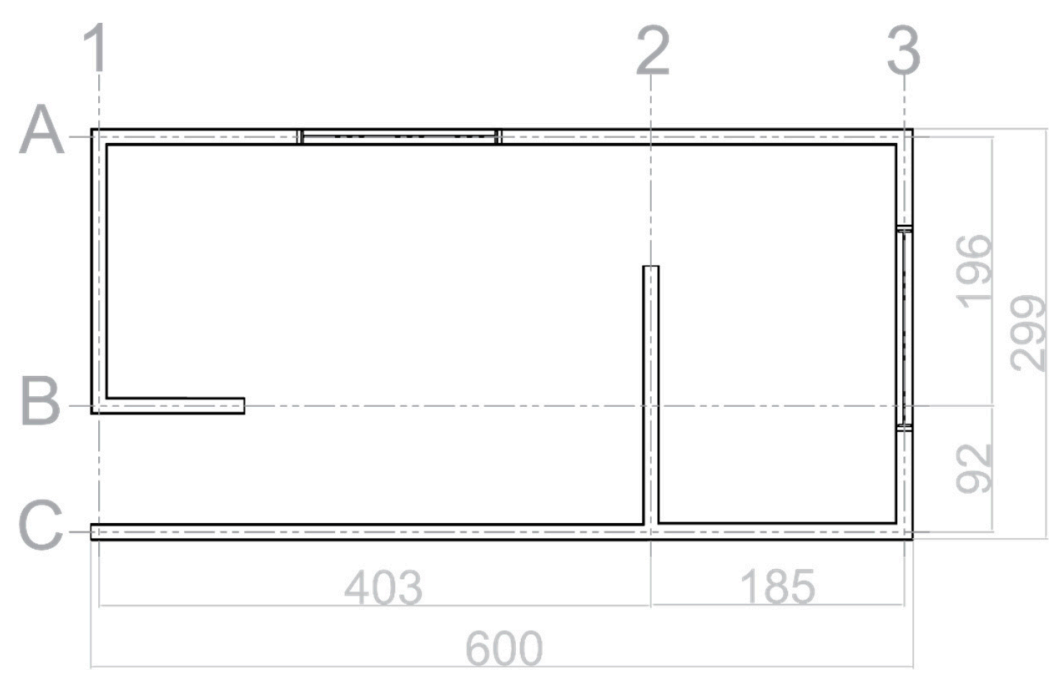

Figure 2. Single-storey house's main dimensions (cm).

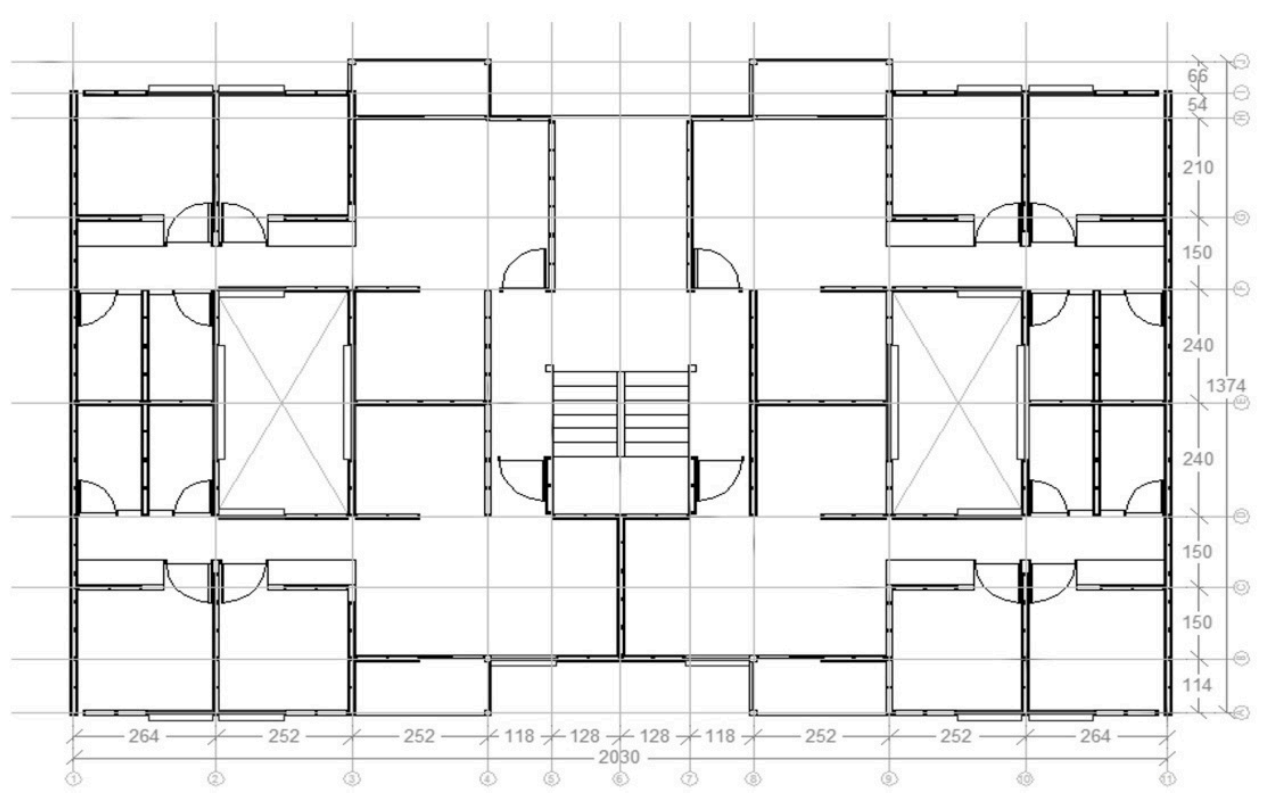

Figure 3. Multi-storey building's main dimensions (cm).

\subsection{Definition of Life Cycle Inventories (LCI)}

The life cycle inventories (LCI) for each of the construction materials used in both functional units were developed and characterized based on the work of Balzarini [54,55] and Zea et al. [54,55]. To calculate the LCIs of the material options, a characterization process was carried out by integrating LCI data and georeferenced data on a geographic information system (GIS). The first step in the characterization process was to calculate the LCIs under three scenarios for a construction material's production efficiency: high performance, mean performance, and low performance, using the specific electricity mix for Colombia. This approach allows the visualization of the range in which the environmental impact might occur, and helps to define the variability within the results and the level of uncertainty. The use of these ranges is invaluable to the development of prospective scenarios. In a second step, the potential transport distances of the materials were calculated from the production centers of bamboo, cement, glue-laminated bamboo, and steel to 12 target cities in Colombia. These production centers and target cities were identified and georeferenced using the GIS software ArcMap [56]. Using 
the spatial analyst features, the geodesic distances between the target city and the production centers were calculated, as can be seen in Figure 4 .

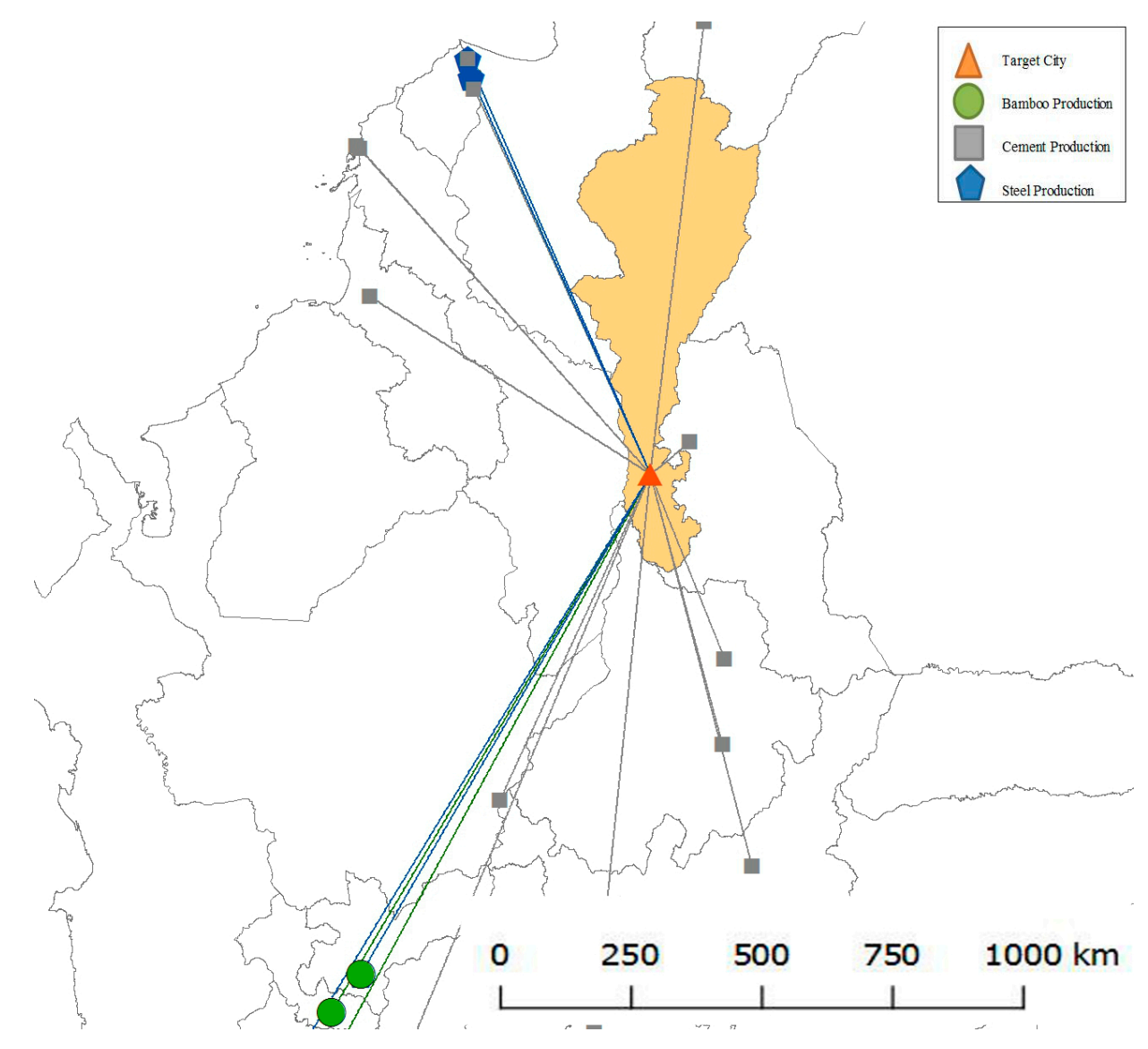

Figure 4. Estimation of construction materials' transport distances for one city.

It has been proposed that there is a logarithmic relation between the area of the country, or major administrative unit, and the potential transport distance of construction materials [57]. With this information, three ranges of transport distances were established for each material option: (i) minimum (closest to the production center), (ii) median (production center in the middle) and (iii) maximum (farthest to the production center). For the modeling of the transport of construction materials, a data set for a 16-t diesel-fueled lorry fleet average was selected from the EcoInvet database [50]. The LCIs for all of the construction materials were developed using the information from the construction materials' production efficiency and their potential transport distances. Each LCI consisted of three scenarios: (i) best-case scenario: high performance and minimum transport distances. (ii) mean scenario: mean performance and median transport distances. (iii) worst-case scenario: low performance and maximum transport distances.

\subsection{Impact Assessment}

The calculation of the life cycle impact assessment (LCIA) data was performed using the IPCC100a evaluation method [51] and SIMApro v8 software [49]. The IPCC100a method considers the emissions $\left(\mathrm{CO}_{2}, \mathrm{CO}, \mathrm{CH}_{4}\right.$, etc.) related to a human activity. In this case, with regard to the extraction and production of construction materials and their transport, subsequently the equivalents in $\mathrm{kg}$ of $\mathrm{CO}_{2}$ are calculated [51]. An important methodological challenge of this section is to account for the $\mathrm{CO}_{2}$ that can be stored by bio-based materials such as bamboo and GLB. Currently, there is no scientific consensus on which is the most appropriated method for $\mathrm{CO}_{2}$ accounting [58]. In order to overcome this challenge, the calculation 
of $\mathrm{CO}_{2}$ balance developed by Zea et al. [31] was proposed. For this step, it is necessary to calculate the amount of $\mathrm{CO}_{2}$ that was captured by the bio-based construction materials, and then subtract it from the $\mathrm{CO}_{2}$ emissions incurred during the extraction and production phases of the construction materials. Furthermore, a similar balance is carried out at the building level by adding firstly all of the $\mathrm{CO}_{2}$ emissions from all of the construction materials, and then subtracting the amount of $\mathrm{CO}_{2}$ stored within the bio-based construction materials within each functional unit [31]. In the context of this study, having a positive $\mathrm{CO}_{2}$ balance means that more $\mathrm{CO}_{2}$ was emitted than what was captured by the bio-based materials, and a negative $\mathrm{CO}_{2}$ balance means that less $\mathrm{CO}_{2}$ was emitted than what was captured by the bio-based materials. Thus, a negative $\mathrm{CO}_{2}$ balance, or negative carbon footprint [59], represents a reduction in atmospheric $\mathrm{CO}_{2}$ for the duration of the service life of the building.

\section{Results}

This section presents the interpretation of the results from the two comparative LCAs carried out. The results presented are in the form of emission per square meter of covered area $\left(\mathrm{kgCO}_{2} \mathrm{Eq} / \mathrm{m}^{2}\right)$ to allow for the comparison between materials and functional units.

\subsection{Life Cycle Impact Analysis}

The results for the evaluation method IPCC100a for SSH and MSB are presented in Figure 5. The columns in this figure present the mean results for the studied construction materials, and the bars represent the high and low performance scenarios for each of them (i.e., the higher point or 'whisker' in the bar represents the low performance scenario, and vice versa). Figure 4 shows that the bamboo-based buildings have the lowest environmental impact for both SSH and MSB. By contrast, brick/concrete $(\mathrm{Br}+\mathrm{Con})$-based buildings have the highest environmental impacts. In the case of single-storey buildings, both bamboo-based buildings have very similar emissions per square meter: close to $80 \mathrm{CO}_{2} \mathrm{Eq} / \mathrm{m}^{2}$. Whilst the bamboo-based multi-storey building has the lowest environmental impact of all in the sample, at only $39 \mathrm{CO}_{2} \mathrm{Eq} / \mathrm{m}^{2}$. This indicates that it is far more effective to use glue-laminated bamboo (GLB) in multi-storey buildings than to use it for single-storey buildings. Moreover, the traditional bamboo technique (bahareque encementado) presents the most promising option to produce low-carbon single-storey buildings.

It is important to note that the brick/concrete $(\mathrm{Br}, \mathrm{CHB}$, and $\mathrm{Br}+\mathrm{Con})$-based buildings present the highest variation in their results, while the bamboo-based buildings have the lowest variation. This suggests that the brick/concrete buildings are more sensitive to variations in the construction materials' production efficiency and transportation than the bamboo-based construction materials. To better understand the reasons behind these results, further assessments were carried out, thus: (i) analysis of the contribution to the environmental impact, and (ii) analysis of the effect of transport distance regimes.

\subsection{Contribution to Environmental Impact}

The results from the contribution to the environmental impact analysis are presented in Table 2. This analysis normalizes the environmental impact of each material and process in terms of the total environmental impact. As can be observed in Table 2, for the bamboo-based building systems (B-SSH, GLB-SSH), the contribution from the transport of construction materials ranges from $33 \%$ to $44 \%$ of their total environmental impact, whilst the bamboo-based construction materials contribution ranges from $4 \%$ to $13 \%$ of the total environmental impact. For the SSH cases (Br-SSH, CHB-SSH, and GLB-SSH), reinforcing steel is one of the main contributors, ranging from $24 \%$ to $37 \%$ of the total impact. Similar results can be observed for the multi-storey buildings, where reinforcing steel contribution ranges from $24 \%$ to $28 \%$ of the total environmental impact. These results support the idea that to in order obtain low carbon, it is necessary to optimize the amount of reinforcement and minimize the distances that the construction materials are transported. Furthermore, certain constructive systems such as GLB or brick can be optimized by improving the production efficiency of a single construction 
material, whereas the traditional bamboo construction (bahareque encementado) would require the optimization of several materials, such as steel, and products, such as cement. In the case of GLB, it is important to remark that the glues used in the lamination process can contribute significantly not only to the environmental impact, but also to the indoor environmental quality of the buildings constructed using GLB. This means that an improvement to the environmental performance of any constructive system requires an effort from many companies.

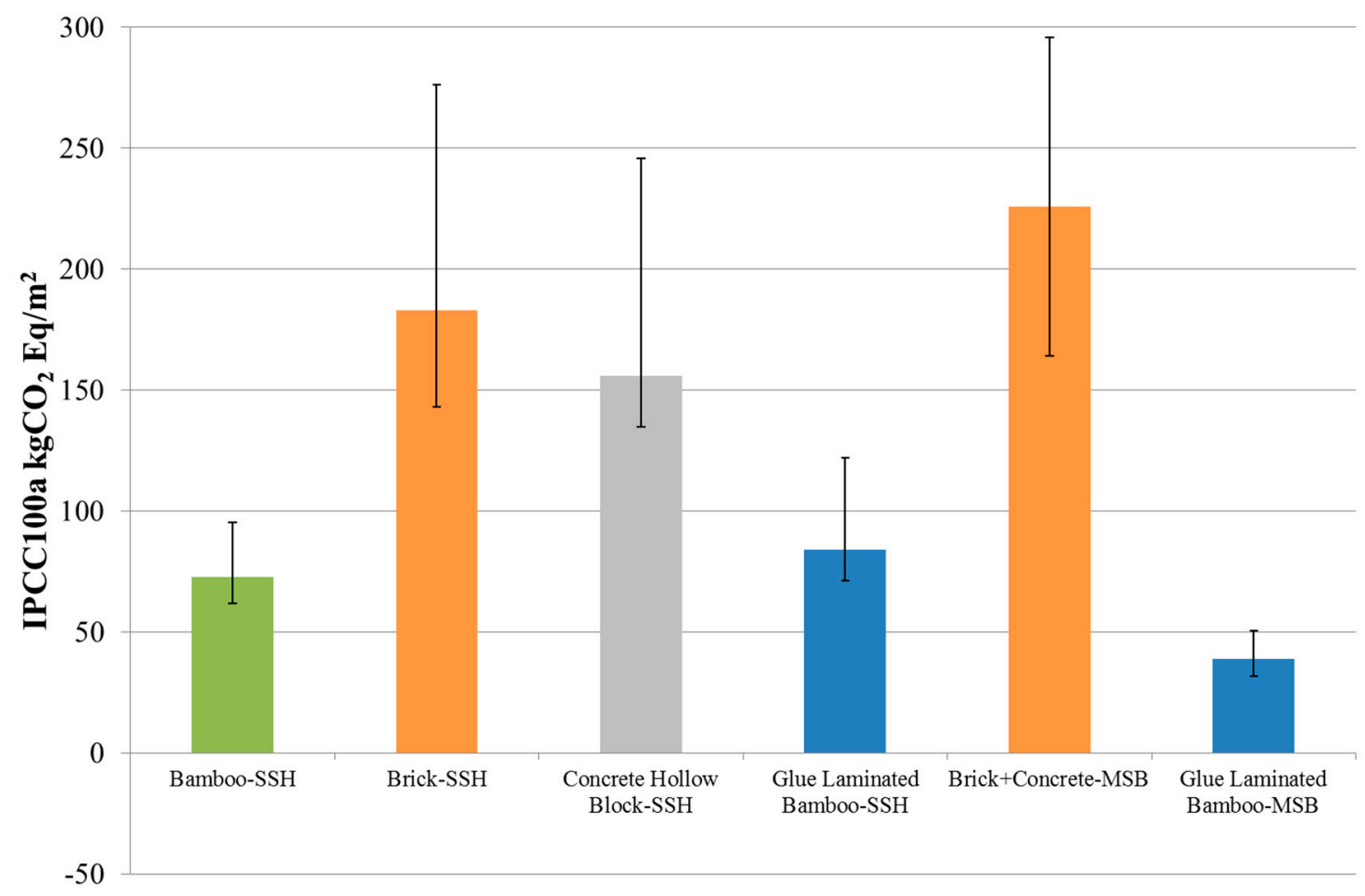

Figure 5. Environmental impact in $\mathrm{kgCO}_{2} \mathrm{Eq}$. SSH: single-storey House; MSB: multi-storey building.

\subsection{Effect of Transport Regimes}

To better illustrate the effect of transport on the environmental impact, the results of the environmental impact were plotted in relation to their weight and kilometers that the materials were transported in $\mathrm{t} \cdot \times \mathrm{km}$; this unit is used to visualize the effect of the weight of the construction materials per functional unit. The result of the effect of transport are presented in Figure 6. In this figure, each constructive system is represented by three points. The lowest point represents the best case, and the highest represents the worst-case scenario. As described in the methodology section, each case represents the combination of production performance and transport. Overall, Figure 6 showcases that the bamboo-based constructive systems have the lowest values for transport of construction materials in terms of mass. Furthermore, it is possible to see that the GLB-MSB has not only the lowest environmental impact, it also requires the least $\mathrm{t} \cdot \mathrm{km}$ from all of the samples. In contrast, the brick-concrete multi-storey building $(\mathrm{Br}+\mathrm{Con}-\mathrm{MSB})$ has both the highest environmental impacts and the highest values for $\mathrm{t} \cdot \mathrm{km}$. It should be noted that even considering the worst-case scenario for the bamboo-based constructive systems, they still produce lower environmental impacts than the best scenarios for mineral-based systems. Moreover, these results show that due to their lightweight, and therefore lower density, bamboo-based construction materials can be transported over longer distances and still have lower environmental impacts. Seen from another perspective, the implementation of local decentralized production centers of bamboo-based construction materials could further reduce the already low environmental impacts associated with the production of bamboo-based buildings. 
Table 2. Contribution to environmental impact analysis

\begin{tabular}{|c|c|c|c|c|c|c|c|c|c|}
\hline $\mathrm{CO}_{2} \mathrm{EQ}$ & $\begin{array}{c}\text { Bamboo Pole } \\
(\%)\end{array}$ & Brick (\%) & $\begin{array}{l}\text { Concrete Hollow } \\
\text { Block (\%) }\end{array}$ & Concrete (\%) & $\begin{array}{c}\text { Flattened Bamboo } \\
(\%)\end{array}$ & $\begin{array}{c}\text { Glue Laminated } \\
\text { Bamboo (\%) }\end{array}$ & Steel (\%) & Timber (\%) & Transport (\%) \\
\hline Bamboo-SSH & 6.4 & 0.0 & 1.8 & 7.9 & 0.2 & 0.0 & 34.7 & 0.0 & 49.0 \\
\hline Brick-SSH & 0.0 & 62.7 & 0.0 & 4.7 & 0.0 & 0.0 & 15.6 & 0.0 & 17.0 \\
\hline $\begin{array}{l}\text { Concrete Hollow } \\
\text { Block-SSH }\end{array}$ & 0.0 & 0.0 & 35.9 & 8.7 & 0.0 & 0.0 & 28.9 & 0.0 & 26.5 \\
\hline $\begin{array}{c}\text { Glue Laminated } \\
\text { Bamboo-SSH }\end{array}$ & 0.0 & 0.0 & 0.0 & 0.0 & 0.0 & 74.4 & 15.5 & 0.0 & 10.1 \\
\hline Brick+Concrete-MSB & 0.0 & 83.6 & 0.0 & 9.3 & 0.0 & 0.0 & 0.1 & 0.0 & 7.0 \\
\hline $\begin{array}{l}\text { Glue Laminated } \\
\text { Bamboo-MSB }\end{array}$ & 0.0 & 0.0 & 0.0 & 19.5 & 0.0 & 54.2 & 0.3 & 11.0 & 15.0 \\
\hline
\end{tabular}

SSH: single-storey house; MSB: multi-storey building. 


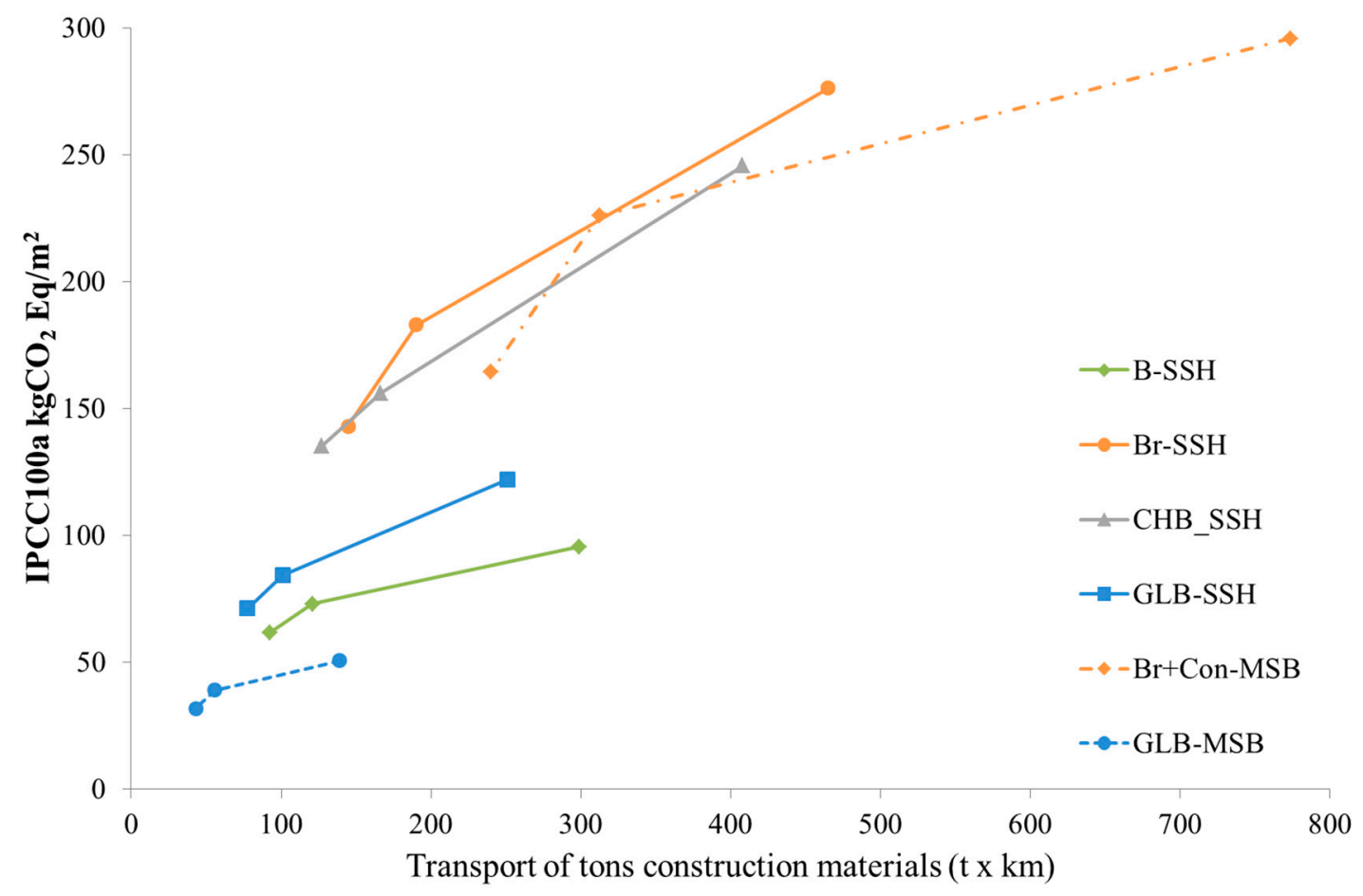

Figure 6. Effect of transport distance to environmental impact. B-SSH: bamboo single-storey house; Br-SSH: brick single-storey house; CHB-SSH: concrete hollow block single-storey house; GLB-SSH: glue-laminated bamboo single-storey house; $\mathrm{Br}+\mathrm{Con}-\mathrm{MSB}$ : brick and concrete multi-storey building; GLB-MSB: glue-laminated bamboo multi-storey building.

\section{Discussion}

The final part of this research was the calculation of the $\mathrm{CO}_{2}$ balance [31] for all the constructive systems. Results from the $\mathrm{CO}_{2}$ balance are presented in Figure 7. This balance accounts for the $\mathrm{CO}_{2}$ that was captured, stored, and emitted for the production of the different construction materials required for the construction of each building type. If these balances are positive, it means that more $\mathrm{CO}_{2}$ was emitted than what was captured and stored within the construction materials. Inversely, a negative balance indicates that more $\mathrm{CO}_{2}$ was stored and captured in the construction materials than what was emitted to the atmosphere during the production of the construction materials. This can be considered as a negative carbon footprint, which in return can be seen as a positive effect on the environment. Figure 6 shows that even under the low-performance scenario (higher whisker in the bar), both bamboo-based constructive systems have the lowest $\mathrm{CO}_{2}$ emissions for both SSH and MSB. For the best-case scenarios (high performance, lower whiskers), both bamboo-based constructive systems present a negative balance, which means that the implementation of these options holds the potential to reduce the levels of atmospheric $\mathrm{CO}_{2}$. It is important to note that engineered bamboo (GLB) has the highest potential to store $\mathrm{CO}_{2}$ per functional unit, due to the amount of bio-based materials used in this system. Nevertheless, the energy demand for the industrialization of these construction materials [5] reduces the amount of $\mathrm{CO}_{2}$ that can be balanced. The traditional bamboo construction system contains less bio-based construction materials, but the materials that are used have a lower environmental impact due to their minimal processing. This allows the traditional bamboo construction to obtain a negative $\mathrm{CO}_{2}$ balance, even under the worst-case scenario conditions. Additionally, the high levels of $\mathrm{CO}_{2}$ captured by the bamboo poles offsets the emissions from the concrete and cement plaster used in the traditional bamboo building system (B-SSH). 


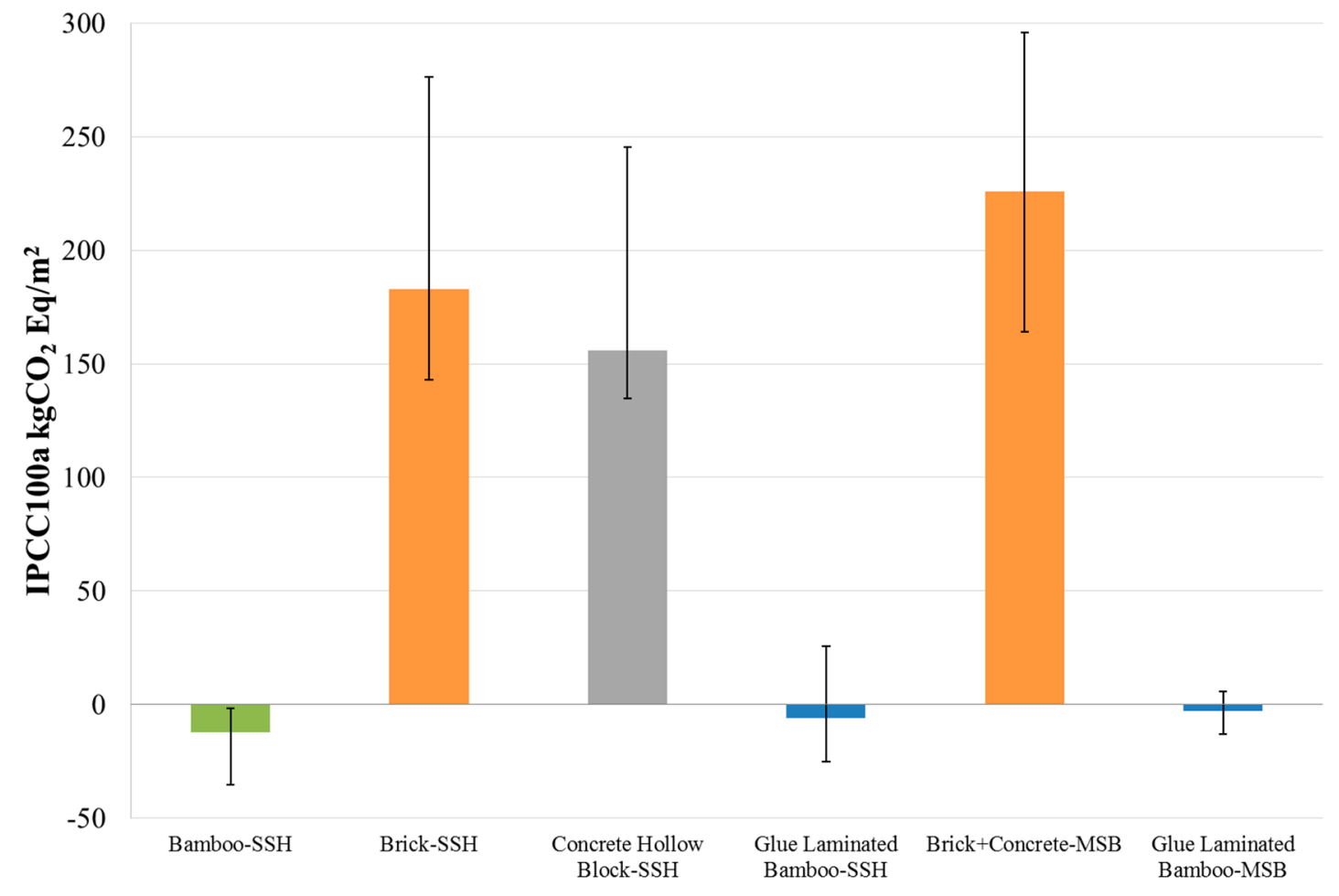

Figure 7. $\mathrm{CO}_{2}$ balance. SSH: single-storey house; MSB: multi-storey building.

A topic for further research is the end-of-life scenarios for the buildings, considering the potential energy gain from the recycling of the bio-based construction materials. The work of Zea et al. [31] has shown that the levels of avoided $\mathrm{CO}_{2}$ emissions can be further increased with the energy gain from recycled bamboo-based construction materials at the end of their life. However, these avoided emissions are directly related to the type of electricity used during the production of the construction materials, and the energy mix used in the country for the production of its electricity. In this case, for Colombia, most of the energy comes from hydropower; therefore, the level of avoided emission that can be considered may not be that significant. Under this perspective, engineered bamboo would withhold the highest potential to produce the lowest environmental impacts from all of the studied construction materials.

\section{Conclusions}

The results showed that brick, reinforcing steel, and transport were the main contributors to the total environmental impact for all of the studied buildings in the Colombian context. This supports the notion that an appropriate selection of construction materials complemented by a rigorous structural design is not only relevant to a building's structural performance, it also affects its environmental impact. It also demonstrates that locally produced construction materials have a significant advantage over those construction materials that require long transport distances. Nevertheless, it is important to note that the contribution from the transportation of construction materials is proportional to the total environmental impact, which means that an increase of transport distance will affect more the results from the buildings that already have higher environmental impacts.

The environmental impact from the bamboo-based construction systems can be further reduced with decentralized production, as well as by improving the current production practices and the electricity mix that is used. Moreover, the use of engineered bamboo provides the lowest environmental impact per functional unit for a multi-storey building, while traditional bamboo construction would be the best option for single-storey houses. On the contrary, the use of bricks and concrete significantly increases the associated emissions. Both industrial and traditional bamboo-based construction systems 
not only produce lower levels of $\mathrm{CO}_{2}$ emissions, they also have the potential to balance the emissions caused by other conventional construction materials, such as concrete and steel, used in the building. This means that every bamboo based-building contributes to reduce the levels of atmospheric $\mathrm{CO}_{2}$ by establishing new and sustainable carbon sinks. Finally, the use of bamboo-based building systems can support bamboo-producing countries in the achievement of sustainable development goals in housing, whilst contributing to the global efforts for $\mathrm{CO}_{2}$ reduction and climate change mitigation.

Author Contributions: The LCA and $\mathrm{CO}_{2}$ methodologies were developed by E.Z.E. and G.H. as part of the $\mathrm{PhD}$ of E.Z. H.F.A. and D.T. contributed to the structural analysis and material quantities for the bamboo frame constructive system. J.F.C.D. and J.S.E.F. contributed to the structural analysis and material quantities for the glue laminated bamboo constructive system.

Funding: Finally, authors also want to acknowledge the funding support received from the Colombian Department of Science, Technology and Innovation COLCIENCIAS, through grant 1204-562-36186 through which information related to the Glue Laminated Bamboo Multi Storey Building was provided.

Acknowledgments: The author would like to thank HILTI AG for their long-term support in the development of the present research project and Amphibia BASE (UK) and Amphibia Group (COL) for providing information and logistical support for this article.

Conflicts of Interest: The authors declare no conflict of interest.

\section{References}

1. UN-DESA. World Population Prospects: The 2015 Revision, Key Findings and Advance Tables; United Nations: New York, NY, USA, 2015.

2. UN-DESA. World Urbanization Prospects: The 2014 Revision; United Nations: New York, NY, USA, 2015.

3. Nam, U.V. Transforming Our World: The 2030 Agenda for Sustainable Development; Division for Sustainable Development Goals: New York, NY, USA, 2015.

4. Simon, D.; Arfvidsson, H.; Anand, G.; Bazaz, A.; Fenna, G.; Foster, K.; Jain, G.; Hansson, S.; Evans, L.M.; Moodley, N. Developing and testing the Urban Sustainable Development Goal's targets and indicators-A five-city study. Environ. Urban. 2016, 28, 49-63. [CrossRef]

5. Salzer, C.; Wallbaum, H.; Lopez, L.; Kouyoumji, J. Sustainability of Social Housing in Asia: A Holistic Multi-Perspective Development Process for Bamboo-Based Construction in the Philippines. Sustainability 2016, 8, 151. [CrossRef]

6. World Cities Report 2016; Nairobi: United Nations Human Settlements Programme; United Nations: New York, NY, USA, 2016.

7. Bribián, I.Z.; Capilla, A.V.; Usón, A.A. Life cycle assessment of building materials: Comparative analysis of energy and environmental impacts and evaluation of the eco-efficiency improvement potential. Build. Environ. 2011, 46, 1133-1140. [CrossRef]

8. Steinberger, J.K.; Krausmann, F.; Eisenmenger, N. Global patterns of materials use: A socioeconomic and geophysical analysis. Ecol. Econ. 2010, 69, 1148-1158. [CrossRef]

9. Dean, B.; Dulac, J.; Petrichenko, K.; Graham, P. The Global Status Report 2016—GABC; UNEP, GABC: Paris, France, 2016.

10. Di Placido, A.M.; Pressnail, K.D.; Touchie, M.F. Exceeding the Ontario Building Code for low-rise residential buildings: Economic and environmental implications. Build. Environ. 2014, 77, 40-49. [CrossRef]

11. Pearce, A.; Ahn, Y.H. Sustainable Buildings and Infrastructure: Paths to the Future; Routledge: Abingdon-on-Thames, UK, 2013.

12. Riaño, N.M.; Londoño, X.; López, Y.; Gómez, J.H. Plant growth and biomass distribution on Guadua angustifolia Kunth in relation to ageing in the Valle del Cauca-Colombia. Bamboo Sci. Cult. 2002, 16, 43-51.

13. Asif, M. Sustainability of timber, wood and bamboo in construction. In Sustainability of Construction Materials; Khatib, J.M., Ed.; Woodhead Publishing: Cambridge, UK, 2009; pp. 31-54.

14. Tellnes, L.G.; Gobakken, L.R.; Flæte, P.O.; Alfredsen, G. Carbon footprint including effect of carbon storage for selected wooden facade materials. Wood Mater. Sci. Eng. 2014, 9, 139-143. [CrossRef]

15. Archila-Santos, H.F.; Ansell, M.P.; Walker, P. Low carbon construction using Guadua bamboo in Colombia. Key Eng. Mater. 2012, 517, 127-134. [CrossRef] 
16. Correal, J. Bamboo design and construction 14. Nonconventional and Vernacular Construction Materials: Characterisation, Properties and Applications; Woodhead Publishing: Cambridge, UK, 2016; p. 393.

17. AIS. Colombian Code for Seismic Design and Construction, NSR-10; Seismic Engineering Colombian Association: Bogotá, Colombia, 2004.

18. Mena, J.; Vera, S.; Correal, J.F.; Lopez, M. Assessment of fire reaction and fire resistance of Guadua angustifolia kunth bamboo. Constr. Build. Mater. 2012, 27, 60-65. [CrossRef]

19. Zea Escamilla, E.; Habert, G.; Lopez Muñoz, L.F. Environmental Savings Potential from the Use of Bahareque (Mortar Cement Plastered Bamboo) in Switzerland. Key Eng. Mater. 2014, 600, 21-33. [CrossRef]

20. Murphy, R.J.; Trujillo, D.; Londoño, X. Life Cycle Assessment (LCA) of a Guadua House. In Proceedings of the International Symposium of Bamboo-Guadua, Pereira, Colombia, 15 September-2 October 2004.

21. De Flander, K.; Rovers, R. One laminated bamboo-frame house per hectare per year. Constr. Build. Mater. 2009, 23, 210-218. [CrossRef]

22. Xiao, Y. Development of Prefabricated bamboo Earthquake Relief Shelter. In Proceedings of the International Conferece of Modern Bamboo Structures, Bogotá, Colombia, 2-3 July 2009.

23. Sharma, B.; Gatoo, A.; Bock, M.; Mulligan, H.; Ramage, M. Engineered bamboo: State of the art. Proc. ICE Constr. Mater. 2014, 168, 57-67. [CrossRef]

24. Trujillo, D.; Archila, H.F. Engineered Bamboo and Bamboo Engineering; TRADA: High Wycombe, Buckinghamshire, UK, 2016.

25. Zea Escamilla, E. Design and Application of Laminated Bamboo Elements in Frame Construction and Mechanical Properties of Laminated Bamboo; Research; Wageningen University: Wageningen, The Netherlands, 2008.

26. Archila Santos, H.F. Thermo-Hydro-Mechanically Modified Cross-Laminated Guadua-Bamboo Panels. Ph.D. Thesis, University of Bath, Bath, UK, 2015.

27. Varela, S.; Correal, J.; Yamin, L.; Ramirez, F. Cyclic performance of glued laminated Guadua bamboo-sheathed shear walls. J. Struct. Eng. 2012, 139, 2028-2037. [CrossRef]

28. Correal, J.; Ramirez, F. Adhesive bond performance in glue line shear and bending for glued laminated guadua bamboo. J. Trop. For. Sci. 2010, 433-439.

29. Ramirez, F.; Correal, J.F.; Yamin, L.E.; Atoche, J.C.; Piscal, C.M. Dowel-bearing strength behavior of glued laminated Guadua bamboo. J. Mater. Civ. Eng. 2012, 24, 1378-1387. [CrossRef]

30. Vogtländer, J.G.; van der Velden, N.M.; van der Lugt, P. Carbon sequestration in LCA, a proposal for a new approach based on the global carbon cycle; cases on wood and on bamboo. Int. J. Life Cycle Assess. 2014, 19, 13-23. [CrossRef]

31. Zea Escamilla, E.; Habert, G.; Wohlmuth, E. When $\mathrm{CO}_{2}$ counts: Sustainability assessment of industrialized bamboo as an alternative for social housing programs in the Philippines. Build. Environ. 2016, 103, 44-53. [CrossRef]

32. Sharma, A.; Saxena, A.; Sethi, M.; Shree, V. Life cycle assessment of buildings: A review. Renew. Sustain. Energ. Rev. 2011, 15, 871-875. [CrossRef]

33. Marjaba, G.E.; Chidiac, S.E. Sustainability and resiliency metrics for buildings-Critical review. Build. Environ. 2016, 101, 116-125. [CrossRef]

34. Reap, J.; Roman, F.; Duncan, S.; Bras, B. A survey of unresolved problems in life cycle assessment. Part I: Goals and scope and inventory analysis. Int. J. Life Cycle Assess. 2008, 13, 290-300. [CrossRef]

35. Reap, J.; Roman, F.; Duncan, S.; Bras, B. A survey of unresolved problems in life cycle assessment. Part II: Impact assessment and interpretation. Int. J. Life Cycle Assess. 2008, 13, 374-388. [CrossRef]

36. Kim, S.; Hwang, T.; Lee, K.M. Allocation for cascade recycling system. Int. J. Life Cycle Assess. 1997, 2, 217-222. [CrossRef]

37. Dubreuil, A.; Young, S.B.; Atherton, J.; Gloria, T.P. Metals recycling maps and allocation procedures in life cycle assessment. Int. J. Life Cycle Assess. 2010, 15, 621-634. [CrossRef]

38. Frischknecht, R. LCI modelling approaches applied on recycling of materials in view of environmental sustainability, risk perception and eco-efficiency. Int. J. Life Cycle Assess. 2010, 15, 666-671. [CrossRef]

39. Gomes, F.; Brière, R.; Habert, G.; Feraille, A.; Lasvaux, S.; Tessier, C. Adaptation of environmental data to national and sectorial context: Application for reinforcing steel sold on the French market. Int. J. Life Cycle Assess. 2013, 18, 926-938. [CrossRef]

40. Langevin, B.; Basset-Mens, C.; Lardon, L. Inclusion of the variability of diffuse pollutions in LCA for agriculture: The case of slurry application techniques. J. Clean. Prod. 2010, 18, 747-755. [CrossRef] 
41. Mutel, C.L.; Hellweg, S. Regionalized life cycle assessment: Computational methodology and application to inventory databases. Environ. Sci. Technol. 2009, 43, 5797-5803. [CrossRef] [PubMed]

42. Hellweg, S.; Mila i Canals, L. Emerging approaches, challenges and opportunities in life cycle assessment. Science 2014, 344, 1109-1113. [CrossRef] [PubMed]

43. Salcido, J.C.; Raheem, A.A.; Ravi, S. Comparison of embodied energy and environmental impact of alternative materials used in reticulated dome construction. Build. Environ. 2016, 96, 22-34. [CrossRef]

44. ISO14040. Environmental Management_Life Cycle Assessment_Principles and Framework; ISO: Geneva, Switzerland, 2007; Volume 14040.

45. Sinha, R.; Lennartsson, M.; Frostell, B. Environmental footprint assessment of building structures: A comparative study. Build Environ. 2016, 104, 162-171. [CrossRef]

46. Säynäjoki, A.; Heinonen, J.; Junnila, S. A scenario analysis of the life cycle greenhouse gas emissions of a new residential area. Environ. Res. Lett. 2012, 7, 034037. [CrossRef]

47. Marsh, R. LCA profiles for building components: Strategies for the early design process. Build. Res. Inf. 2016, 44, 358-375. [CrossRef]

48. Chastas, P.; Theodosiou, T.; Bikas, D. Embodied energy in residential buildings-towards the nearly zero energy building: A literature review. Build. Environ. 2016, 105, 267-282. [CrossRef]

49. Pre-Consultants. SIMA Pro v7.3.3. Available online: http://www.pre-sustainability.com/simapro-installation (accessed on 27 August 2018).

50. SCLCI. EcoInvent Database. Available online: http:/ /www.ecoinvent.org (accessed on 27 August 2018).

51. Edenhofer, O.; Pichs-Madruga, R.; Sokona, Y.; Farahani, E.; Kadner, S.; Seyboth, K. IPCC, 2014: Climate Change 2014: Mitigation of Climate Change. Contribution of Working Group III to the Fifth Assessment Report of the Intergovernmental Panel on Climate Change; Cambridge University Press: Cambridge, UK; New York, NY, USA, 2014.

52. CSN EN 15978 Sustainability of Construction Works-Assessment of Environmental Performance of BuildingsCalculation Method; European Standards: Brussels, Belgium, 2011.

53. Zea Escamilla, E.; Habert, G. Method and application of characterisation of life cycle impact data of construction materials using geographic information systems. Int. J. Life Cycle Assess. 2016, 22, 1210-1219. [CrossRef]

54. Zea Escamilla, E.; Habert, G. Regionalizing the Environmental Impact of Bamboo-Based Buildings by Integrating Life Cycle Assessment with Geographic Information Systems. In A Comparative Case-Study in Colombia, Proceedings of the World Bamboo Congress, Damyang, South Korea, 17-22 September 2015; World Bamboo Organization: Plymouth, MA, USA, 2015.

55. Balzarini, A. Environmental Impact of Brick Production Outside Europe; Research; Swiss Federal Institute of Technology ETH Zürich: Zürich, Switzerland, 2013.

56. ESRI. ArcGIS for Desktop. Available online: http://www.esri.com/software/arcgis/arcgis-for-desktop (accessed on 27 August 2018).

57. Zea Escamilla, E.; Habert, G. Global or local construction materials for post-disaster reconstruction? Sustainability assessment of twenty post-disaster shelter designs. Build. Environ. 2015, 92, 692-702. [CrossRef]

58. Tellnes, L.; Ganne-Chedeville, C.; Dias, A.; Dolezal, F.; Hill, C.; Zea Escamilla, E. Comparative assessment for biogenic carbon accounting methods in carbon footprint of products: A review study for construction materials based on forest products. IFor.-Biogeosci. For. 2017, 10, 815. [CrossRef]

59. Thøgersen, J.; Nielsen, K.S. A better carbon footprint label. J. Clean. Prod. 2016, 125, 86-94. [CrossRef]

(C) 2018 by the authors. Licensee MDPI, Basel, Switzerland. This article is an open access article distributed under the terms and conditions of the Creative Commons Attribution (CC BY) license (http:// creativecommons.org/licenses/by/4.0/). 